This article was downloaded by: [New York University]

On: 10 May 2015, At: 00:16

Publisher: Routledge

Informa Ltd Registered in England and Wales Registered Number: 1072954

Registered office: Mortimer House, 37-41 Mortimer Street, London W1T

3J H, UK

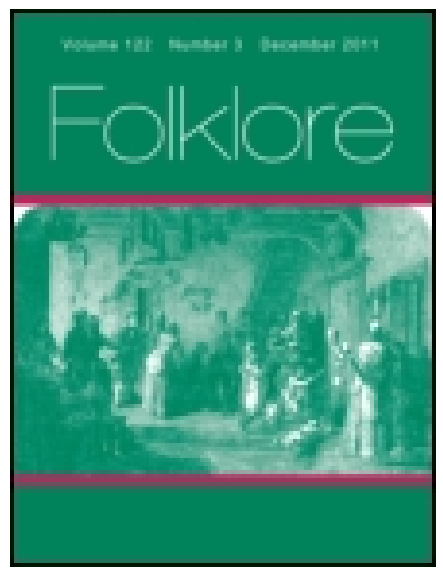

\title{
Folklore
}

Publication details, including instructions for authors and subscription information:

http:// www. tandfonline.com/loi/ rfol20

\section{The Silver Bough in Irish Legend.}

Eleanor Hull

Published online: 06 Feb 2012.

To cite this article: Eleanor Hull (1901) The Silver Bough in Irish Legend., Folklore, 12:4, 431-445, DOI: 10.1080/ 0015587X.1901.9719649

To link to this article: http:// dx.doi.org/ 10.1080/ 0015587X.1901.9719649

\section{PLEASE SCROLL DOWN FOR ARTICLE}

Taylor \& Francis makes every effort to ensure the accuracy of all the information (the "Content") contained in the publications on our platform. However, Taylor \& Francis, our agents, and our licensors make no representations or warranties whatsoever as to the accuracy, completeness, or suitability for any purpose of the Content. Any opinions and views expressed in this publication are the opinions and views of the authors, and are not the views of or endorsed by Taylor \& Francis. The accuracy of the Content should not be relied upon and should be independently verified with primary sources of information. Taylor and Francis shall not be liable for any losses, actions, claims, proceedings, demands, costs, expenses, damages, and other liabilities whatsoever or howsoever caused arising directly or indirectly in connection with, in relation to or arising out of the use of the Content.

This article may be used for research, teaching, and private study purposes. Any substantial or systematic reproduction, redistribution, reselling, loan, sub-licensing, systematic supply, or distribution in any form to anyone is 
expressly forbidden. Terms $\&$ Conditions of access and use can be found at http://www.tandfonline.com/page/terms-and-conditions 


\section{THE SILVER BOUGH IN IRISH LEGEND.}

BY ELEANOR HULI.

IN the early chapters of Mr. Frazer's Golden Bough the author, following the Commentary of Servius, connects the rites performed at Nemi with the allusion of Virgil to the bough plucked by command of the Sibyl and carried by Eneas into the under-world. So far as the present writer is aware, there is no other and no better ground for the connection than this one passage from Servius. The references given by the author to Pausanias, Strabo, and Suetonius, do indeed bear upon the legend and the rites of the Grove of Aricia, but none of them suggest any further tradition connecting the bough broken off by the runaway slave within the sanctuary of Nemi, with the Golden Bough plucked near the entrance to Avernus from the wondrous tree sacred to "Infernal Juno" (i.e., Proserpine), without which none might enter the realm of Pluto. Is there, in fact, any likelihood that such a connection really existed?

Without unduly emphasising the fact that Servius lived nearly 400 years later than Virgil, we would remind the reader that Servius is a voluminous writer, who drags in every possible and impossible allusion collected in the course of a laborious life, however remotely bearing upon the matter in hand, which can by any means be used to illustrate his subject. He is quite devoid of the power of discrimination, and his work is rather to be regarded as a repository of legends, many of 'which might otherwise have been lost, than as a trustworthy guide to the origin of any particular tradition. Nothing indeed could better illustrate his system of gathering together and setting down every allusion occurring to his well-stocked mind, which bore in the most distant way upon the subject in hand, than his treatment of this very point. Here is the 
passage: "Licet de hoc ramo hi qui de sacris Proserpinæ scripsisse dicuntur, quiddam esse mysticum affirment ; publica tamen opinio hoc habet. Orestes post occisum regem Thoantem in regione Taurica cum sorore Iphigenia. . . . ." (Here begins the story of the flight of Orestes with Iphigenia and of the carrying off of the statue of Diana, as related by Mr. Frazer.) “. . . . Nunc ergo istum inde sumpsit colorem. Ramus enim necesse erat ut et unius causa esset interitus unde et statim mortem subiungit Miseni : et ad sacra Proserpina accedere, nisi sublato ramo, non poterat. Inferos autem subire hoc dicit sacra celebrare Proserpinæ. . . . ." (Servius, Enn., vi., 136 sqq.) After which, Servius wanders into a discussion of the doctrine of Pythagoras that life is like the letter $Y$, in which he finds again the symbol of the branch in the dividing ways of good and evil.

We may read the passage in English as follows :-

"Although such as are said to have written on the rites of Proserpine assert of this branch that there is something mystic in it, the current view is as follows. Orestes, after the slaying of king Thoas in the Tauric district, fled with his sister Iphigenia. . . . . Now therefore he (i.e. the poet) has coloured his story from this source. The branch had to be the cause of one death; wherefore he adds at once the death of Misenus: and he could not join the rites of Proserpine without having the branch to hold up. And by 'going to the shades' he (the poet) means celebrating the rites of Proserpine." 1

2 I am indebted to the kindness of Mr. W. II. D. Rouse for the above translation. With reference to the phrase " non poterat," Mr. Rouse adds : "I think poterat is used loosely, as if Eneas had been meant, when the writer should have said 'a man.' Eneas was to pluck the bough because he "could not join, \&c., to imply that none could. Not Misenus, certainly, is meant; grammatically, the poet ; by intent, Eneas ; by implication, anyone."

Miss Burne suggests that Servius must have seen in his own lifetime the last days, perhaps the final extinction, of the "Rites of Proserpine," $i$.e. the famous Eleusinian Mysteries. This throws an interesting light on his use of the imperfect, poterat. 
It will be seen that Servius endeavours to rationalise the story by connecting it with the Orestes legend and the death of Misenus, adding that he derives the former connection from a current tradition, popular in his day. That there was some such confused popular tradition is likely enough, but it seems to have had as little foundation in the thought of Virgil as had the further suggestion that the bough represented to Virgil the diverging paths of virtuous and evil living, represented by the letter $Y$ of Pythagoras. As explanations of the bough of Eneas, both seem to be equally far-fetched ideas. ${ }^{1}$

The point in no way touches Mr. Frazer's main line of argument, derived from a consideration of the rites of $\mathrm{Nemi}$, and it might not have been worth while to call attention to it, but that it would seem a pity that a modern scholar should give prominence to a far-fetched theory of post-classical origin, to explain an episode so full of beautiful and mystic meaning as the plucking of the bough before entering the under-world. It certainly had no such cut-anddry rationalistic meaning in the mind of the poet. Even Servius recognises an older meaning, though it had become faded and obscured in his day, when he says, "Such as have written on the rites of Proserpine assert of this branch that there is something mystic in it." And again, "He could not take part in the rites of Proserpine without having the branch to hold up, and by 'going to the shades' he means celebrating the rites of Proserpine ;" that is to say, the- well-known and constantly recurring Mysteries of Eleusis, in which the disappearance of the Maiden into

I Since writing the above, my attention has been drawn to the passage in Mr. Andrew Lang's recent book Magic and Religion, pp. 207-9. In the main his view of Servius' methods agrees with the above, but he does not appear to be aware of the Irish folklore belief. It is far more likely that Virgil took his legend from prevalent tradition than that he "invented" it. I can see no connection between the Golden Bough and the drawing of Arthur's sword, which belongs to a different set of legends, viz. the herotest series. 
Hades was continually re-enacted. Here Servius endeavours to explain away the supernatural element in the history of Eneas, and to that end credits Virgil with an allegorical method of relating history. Again, the branch could not have caused the death of Misenus, as Misenus was dead before the bough was plucked. This seems a wholly gratuitous addition on the part of Servius to support his theory. Nor can it be said that the branch had a connection with the burial, for the surprise of Charon at the sight of the Bough, "so rarely seen" in Hades, shows that it was only those who entered the realms of the dead during life who presented the branch to Proserpine. She herself was a native of the upper world, dwelling in the shades, but able to return to earth at intervals. Hence, no doubt, the need that the living man who would enter Hades and return, should appear there in the character of her votary. The connection with the death of Misenus was simply that the truth of the Sibyl's announcement with regard to -Misenus strengthened the belief of Eneas in the righteousness of her further command to pluck the bough.

The idea of the poet is wholly different from that of his commentator. In Virgil, the Golden Bough, which grew concealed in the shades of gloomy woods, and could only be gathered "the fates permitting," was dedicated to Proserpine. It was to be presented to her as her peculiar gift. It could never come to an end, because no sooner was one bough broken off than another succeeded it. It was this shining bough, plucked by Eneas, and carried by the Sibyl, that gained them admission into Hades. When Charon withstood their passage, refusing to ferry living beings across the Stygian lake, the Sibyl "showed the shining bough, concealed within her breast."

\footnotetext{
"Nor more was needful; for the gloomy god Stood mute in awe to see the golden rod; Admired the destined offering to his queen, A venerable gift, so rarely seen."
}

(Dryden's-Translation.) 
With limbs and body cleansed with water, Eneas later approaches the gate of Pluto's palace, and "fixes the fatal bough required by his queen above the porch." The Golden Bough was thus plainly a talisman, empowering the bearer to enter in safety during his lifetime the under-world. It was the property of the queen of the unseen abode. ${ }^{1}$

Now it is interesting to find the same idea running through a number of very early pagan legends derived from Gaelic or Irish sources. We propose to throw together a few of these examples, gathered out of that large storehouse of visions regarding the unseen world which Irish literature provides us with. Probably these surviving visions or voyages are only the remains of a body of legend originally extending far beyond Ireland, though some of the conceptions which we find in them seem special to the Western Gael. The bough in Irish legend was not intended to avert the anger of the gods of the under-world, who are always represented as craving for the presence of the chosen being; it is rather the gift of the queen or presiding genius of the Land of the Ever Living and Ever Young, to draw to her domain the favoured mortal on whose companionship her heart is set. For the mortal generally enters by invitation, and the branch is held out as a clue binding the desired 'one to enter her abode. It acts the double part of a link to the unseen world and of a means of sustenance while there. Often also it produces sweet and soothing music, which both allures the mortal, and wiles into forgetfulness the bereaved who are left behind. The Irish conception of the unseen differs so entirely from the classical, that it is only to be expected that the functions of the bough should differ slightly also. The idea of torture, pain, or expiation for sin never enters into the Celtic future. His Elysium is wholly happy; the Plain of Flowers, the

1 In G. B., iii., $455, n$ 5, Mr. Frazer seems suddenly to revert to this idea, though the whole of his previous argument hangs upon the bough bearing a different signification. 


\section{$43^{6}$ The Silver Bough in Irish Legend.}

Land of Youth, the Country of the Ever-living, the Plain of Honey, these are his names for it. It is only after the introduction of Christianity that these joyous ideas become overshadowed by gloom, and the conception of guilt and "expiation fills the canvas.

Let us take first a vision which in its structure and substance retains, with very little infusion of Christian elements, its pagan form and feeling. The Voyage of Bran, Son of Febal, describes the visit of Bran to the Elysium of the pagan Celt. It begins thus: "It was fifty quatrains that the woman from the unknown land sang on the floor of the house to Bran, son of Febal, when the royal house was full of kings; they knew not whence the woman had come, for the ramparts were closed. This is the beginning of the story. One day in the neighbourhood of his stronghold Bran went about alone, when he heard music behind him. As often as he looked back it was still behind him the music was. At last he fell asleep at the sound of the music, such was its sweetness. When he awoke from his sleep he saw close by him a branch of silver with white blossoms, so that it was not easy to distinguish the blossoms from the branch. Then Bran took the branch in his hand to the. royal house. When the hosts were in the royal house, they saw a woman in strange raiment on the floor of the house. 'Twas then she sang the fifty quatrains to Bran, the host listening, and all beholding the woman. And she sang:

\footnotetext{
- A branch of the apple-tree from Emain

I bring, like those we know;

'Twigs of white silver are on it

'Crystal brows with blossoms, \&c.'
}

Thereupon the woman went from them and they knew not whither she went. : And she took her branch with her. The branch sprang from Bran's hand into the hand of the woman, nor was there strength in Bran's hand to hold the branch." 1

'Edited by Dr. Kuno M yer in Mr. Nutt's Voyage of Bran, vol. i. 
We would note, in passing, that the branch is always said to be the bough of an apple-tree, and we shall see in future extracts that the apples of the branch served for meat and drink in the Land of Promise. They tasted of every sort of delicious flavour, and their sustenance lasted during the whole sojourn of the visitor to the invisible world. The tree is described in the Sickbed of Cuchulainn as growing in Magh Mell, "the Plain of Honey," another name for the Irish Elysium.

\footnotetext{
"There is a tree at the door of the Court, It cannot be matched in harmony,

A tree of silver upon which the sun shines,

Like unto gold is its splendid lustre.

"There are at the eastern door

Three stately trees of crimson hue, From which the birds of perpetual bloom Sing to the youth from the kingly rath."
}

Mr. Frazer takes it for granted that the Golden Bough of Virgil, and also that cut by the fugitive at Nemi, which in his view were the same, but to our mind were 'probably unconnected, was the mistletoe. ${ }^{1}$ This is possible, but it is worth remark that this plant, though we learn from Latin authors that it played a part in the religious ceremonies of the pagan Celts of Britain and Gaul, is seldom if ever mentioned in lrish literature. The ceremonial cutting of the mistletoe bough either belonged to a later system of things than that described in Irish Gaelic litera. ture, or it was confined to the more Easterly branches of the Celtic race. ${ }^{2}$ The yew was the tree from which the Irish Druid's wand of divination was made, and it is the appletree that plays the greatest part in his romance. In the Voyage of Bran the talisman given by the unknown

I' It is nowhere stated that the bough of Eneas was the mistletoe. Virgil compares it to the mistletoe, which, as Mr. A. Lang remarks, argues to the contrary.

I believe the mistletoe was rare in Ireland. 
woman to Bran, is said to be " a branch of the apple-tree from Emain," i.e., the kingly residence of the Kings of Ulster, the earthen ramparts of which still exist not far from Armagh. Now the three halls or forts of this ancient palace were called the Royal Branch (Craebh Ruadh), the Red Branch (Craebh Derg), and the Speckled House (Teiti Brec); while the bodyguard or knights of the king were styled Champions of the Royal Branch. It was only by special proficiency in the arts of combat that admittance into this order was gained. So far as is known to the writer, the origin of these names is lost: could we regain their significance, some light would probably be thrown upon the choice of the "apple-tree of Emain" as the magic talisman insuring safety and nourishment in the invisible world.

But to turn to another story. We meet the silver branch again in a tale entitled Cormac's Adventure in the Land of Promise. ${ }^{1}$ The youth who acts the hero of this tale was one of the most famous kings of early Ireland. The portion of the tale bearing upon this point runs as follows:- "One day at dawn in May-time, Cormac, grandson of Conn, was alone on Mur Tea in Tara. He saw coming towards him a sedate, grey-headed warrior. A branch of silver with three golden apples on his shoulder. Delight and amusement to the full was it to listen to the music of that branch, for men sore wounded, or women in child-bed, or folk in sickness, would fall asleep at the melody which was made when that branch was shaken." The warrior tells Cormac that he comes from a land wherein is naught but truth; where is neither age nor decay, nor gloom, nor sadness, envy nor jealousy, hatred nor haughtiness. Cormac begs the warrior to give him the branch. This the unknown consents to, on condition that he receives in return any three boons that he shall ask.

' Edited by Dr. Whitley Stokes, Irische Texte, vol. iii., pp. I83-229. 
On getting Cormac's promise, he gives the branch to the young prince, and disappears, Cormac knows not whither. Cormac returns to his palace. He shakes the branch and deep slumber falls on all. But at the end of a year the warrior returns and demands in succession the three boons promised him by Cormac. They are Cormac's daughter Ailbe; his son, Cairpre Lifechair; and finally Cormac's wife, Ethne the Tall. Twice Cormac uses the magic bough to sooth the grief of the survivors, but the third time he follows the messenger into the invisible land, where he finds his wife, and sups with her and his children in a country of wonderful happiness. He finds that it was Manannan mac Lir who drew away his wife, the same god who interferes between Cuchulainn and Fand in The Sickbed of Cuchulainn, and who probably was conceived of as the ruler of the unseen world. In the latter story it is a cloak that he shakes between the seen and unseen to hide the invisible world from Cuchulainn. The cloak seems here to have for some reason replaced the branch. The close of the story of Cormac's adventure in the Land of Promise is that Cormac gets the Cup of truth and the Branch of music and joy, and returns home.

The branch performs the double function of sustaining life by providing nourishment and of producing sounds of entrancing harmony. There may be a connection, conscious or unconscious, between this latter power possessed by the branch and the symbolic branch carried by the bards as a sign of their profession. The purpose of the branch (Craebh Ciuil) was exactly the same as that described above; it was used to bring about peace and order in moments of excitement, and its authority seems never to have been questioned. The shaking of the bardic wand, which seems to have been a little spike or crescent, with gently-tinkling bells upon it, quieted the most turbulent assembly. For instance, in the piece called Mesca Ulad, in the midst of a bloody fray, the chief poet of Ulster, 


\section{The Silver Bough in Irish Legend.}

Sencha, arose "and waved the peaceful branch of Sencha, and all the men of Ulster were silent, quiet;" while in another passage in the same piece, he is described as "bearing a bronze branch at the summit of his shoulder." His title of "pacificator of the hosts of Ulad" probably comes from this. In another piece entitled Agallamh an da Shuadh or the Dialogue of the two Sages, the symbol is thus described: "Neidhe" (a youthful bard who aspired to succeed his father as chief poet of Ulster), "made his journey with a silver branch over him. The Anradhs, or poets of the second order, carried a silver branch, but the Ollamhs, or chief poets, carried a branch of gold; all other poets bore a branch of bronze." The King of Ulster also had in his palace, at the right hand of his seat at table, a bronze post, which he struck with his wand or sceptre of silver, and which had the same instantaneous effect of pacifying, feuds between his followers. In the tales of the Irish Elysium, there may be some remembrance of these well-known kingly and bardic boughs of Peace.

In the story of Conla Ruadh, the maiden who calls him away uses a single apple as a bait to draw him to fairyland. He is the son of a famous monarch of early Ireland, Conn, the fighter of a hundred (Cet-da-thach) and the story seems to have been told to explain why his brother Art, the succeeding king, should have been named "the Solitary.". Conn and his son Conla were seated together one day on the hill of Usnech in Meath, when Conla perceives a beautiful maiden, visible only to himself, who speaks to him and invites him to join her in Magh-Mell (viz. the "Plain of Honey," one of the Irish names for Elysium).

The king is, startled at the abstraction into which the vision has thrown Conla, and frightened at hearing him converse with an invisible being. He hastily sends for his Druids to exorcise his : son and chant their incantation against the invisible syren, who disappears. "But when the chant of the Druids was driving her away, she threw an 
apple to Conla. For a full month Conla ate nothing but this apple; no bit nor drink beside it passed his mouth, for he deemed all other food poor and unworthy beside that apple. Yet, however much he ate of it, nothing was gone from the apple ; it was still quite whole." At the end of a month the lady appears again, beseeching him to come and reign as King over the Ever-living Ones, the people of Tethra, Ocean King. Conla is grieved and perplexed between his duty to his kingdom and his strong desire to go; and seeing him wavering, the lady breaks out into song, describing in terms so ravishing the joys and glories of the Land of the Living, that he gives one spring into her "very strong, wellbalanced, gleaming curach" and disappears. "And it is not known whither they went."'

In the next story that attracts our attention, however, we learn "whither they went." In it the same hero plays a part. We meet Conla again in the semi-Christian tale of Teigue, Son of Cian. It is, like so many of the Irish stories of the unseen world, thrown into the form of a voyage. The invisible world is conceived of sometimes as being beneath the hills, and entered through the tumuli that in several places in Ireland mark the burial places of early heroes or gods; or as being far over the seas, and approachable either by boat or by means of a magic horse which rides across the waves, and which carries the chosen hero to the land of happiness. There is quite a large literature, full of imagination and romance, dealing with these voyages; a literature that is exceptionally interesting as showing the gradual modification of thought brought about by the infusion of Christian ideas. The two most important points regarding the pagan conception, unadulterated by Christianity, are (I) that the Irish unseen world was a land of absolute delight, unclouded by any idea of pain or expiation

\footnotetext{
' Eđited by O'Beirne Crowe, Kilkenny Archaological Journal, 1874-5, p. 118 , etc.
} 


\section{The Silver Bough in Irish Legend.}

for $\sin$; (2) that it was not attained through death: but generally at the call or invitation of an inhabitant of the invisible world, often a woman who sets her love upon some human being and entices him away. The passage from the story of Teigue, Son of Cian, bearing on our point is as follows:-

"Now for all they had suffered of cold, of strain on their endurance, of foul weather, and of tempest, yet after reaching the coast on which they were thus landed, they felt no craving at all for fire or for meat; the perfume of that region's fragrant crimsoned branches being meat and satisfying nourishment for them. Through the nearest part of the forest they take their way, and come by-and-by upon an orchard full of red-laden apple-trees, with leafy oaks too in it, and hazels yellow with nuts in their clusters. They quit this spot and happen on a wood; great was the excellence of its scent and perfume; round purple berries hung on it, and every one of them bigger than a man's head. Birds beautiful and brilliant feasted on these grapes; they were fowls of unwonted kind: white, with scarlet heads and golden beaks. As they fed, they warbled music and minstrelsy exquisitely melodious, to which the sick of every kind and the many times wounded would have fallen asleep, and Teigue hearing; chanted this melody: 'Sweet to my fancy, as I consider them, the strains of this melody to which I listen.' "'

They advance over a plain, clad in flowering clover all bedewed with honey, and enter a fort with a silver rampart in the "Earth's Fourth Paradise," where they find a charming youthful couple, with torques of gold about their necks. "Now the youth held in his hand a fragrant apple having the hue of gold ; a third part of it he would eat, and still, for all he consumed, never a whit would it be diminished. This fruit it was that supported the pair of them, and when

\footnotetext{
' Edited by Dr. Standish Hayes O'Grady, Silva Gadelica, pp. 342-359.
} 
once they had partaken of it, nor age nor dimness could affect them."

The youth explains that he is Conla and that he has been drawn away by the girl of many charms who sits beside him. Then as they wander round the splendid mansion, now empty, but reserved "for the righteous kings who after acceptance of the Faith shall rule Ireland," Teigue looks away across the capacious palace and "marks a thickly furnished wide-spreading apple tree that bore both blossoms and ripe fruit at once. "What is that apple tree yonder ?' he asked, and she made answer: 'That apple tree's fruit it is that shall serve for meat for all who come to this mansion, and a single apple of it was that which coaxed away Conla to me." "

The pagan idea of the apple-branch as a talisman is, in such semi-Christian visions as the above, evidently becoming confused with the idea derived from Biblical sources of the tree in the midst of the Christian Paradise; yet its original meaning is not entirely lost. In the visions in which the Christian idea is paramount, such as the Vision ascribed to Adamnan, or the piece entitled the Two Sorrows of Heaven's Kingdom, the nution of the talisman is altogether lost, while the idea of the tree of nourishment, which is pagan and Christian alike, remains. The birds of pagan legend inhabiting its boughs become in the later visions the souls of the righteous in the form of birds. In the Voyage of Brendan we find, amid many details inspired by Christian tradition, a confused remem. brance of the fair maiden of the pagan tales, in the monstrous maiden, "smooth, full-grown, yellow-haired, whiter than snow or the foam of the wave" who is found floating dead upon the ocean, and is brought to life by Brendan in order that she may be baptised and receive the Sacrament, "before going at once to Heaven."

In the Ossianic tale of Oisin in Tir-na-nog, the wanderers, Oisin (Ossian) and the beautiful maiden who entices him 


\section{The Silver Bough in Irish Legend.}

away, meet, twice in their voyage "a lovely young maiden riding the waves on a brown steed, with a golden apple in her hand, followed by a young warrior on a white steed, who closely pursued her." In the Voyage of Maelduin a similar idea is latent in the rod plucked by the voyager from the wood as they were passing, which sprouted on the third day with a cluster of three apples, and each of these apples sufficed them for forty nights.

Putting together all these examples, which no doubt might be added to from other sources, may we not ask, is not the Gaelic Apple-Bough of entrance into the unseen world nearer in idea to the conception of Virgil than the legend of the bloody sacrifice within the groves of Nemi, or the story of the flight of Orestes from which this is supposed to have had its origin? In both, the mortal entered alive into the unseen world, guided by the bough; in: both, the bough, though in classic tradition it grew above Avernus, while in Irish tradition it grew in the invisible land itself, was the special property of the presiding goddess of that world. It would be curious if a folk-belief, once perhaps widely-spread, had been retained only in the verse of Virgil, and the folk-tradition of Ireland.

[Miss Hull suggests that her examples of Magic Boughs may be added to from other sources. : The following passage from Grimm's Deutscha Mythologie seems pertinent to the subject. (Stallybrass' translation, vol. iii., pp. 97 I sqq.) He is dealing with the widespread German legends of departed heroes slumbering in hidden caverns, and of white ladies inhabiting the recesses of the mountains, with whom is usually commonly associated the notion of an enchanted yet recoverable treasure.

"To get into the mountain in which it is concealed, one usually needs a plant or root to clear the way, to burst the door. The folktales simply call it a beautiful wonderflower, which the favoured person finds and sticks in his hat ; all at once entrance and exit stand open for him to the treasure of the mountain. If inside the cavern he has filled his pockets, and bewildered at the sight of the valuables has laid aside bis hat, a warning voice rings in his ear as he departs, Forget. not the best / but it is then too late, the iron door shuts with a bang, hard upon his heel, in a twinkling all has disappeared and the road is never to be found again. The same formula comes up regularly every time 


\section{The Silver Bough in Irish Legend. 445}

in the legends of the Odenberg, of the Weser mountains, and the Harz, and in many more (D. Sag., nos. 9, 303, 314. Bechst. 1, 146, 3, 16, 4, $210-1$. Dieffenbach's Wetterau, pp. 284-5, 190); it must be very old. The flower is commonly said to be blue, the colour most proper to gods and spirits, yet also I find 'purple flower' and 'white flower' mentioned. Sometimes it is called Schlïsselblume (keyflower) because it locks the vault, and as symbol of the key-wearing white woman whom the bunch of keys befits as old mistress and housekeeper, and who has likewise power to unlock the treasure; also luckflower (Bechst. 3, 212), but most frequently wunderblume. When three wonder. flowers are named, it seems to mean three on one stalk (ib. I., 146, 4, 209)."

Instead of wonderflower or keyflower, other stories name the springrwurzel (explosive root) supposed to be the euphorbia lathyris, which the Italians call sferra-cavallo, because its power over metals is so great that a horse stepping on it has to leave the shoe behind. A foot-note refers to the rock-splitting plant Shamir, of Rabbinic legend. From this he passes to the use of the wish-rod, or divining-rod, called in the description of the Hoard of the Nibelungs ( $\mathrm{Nib}$. 1064) "a rodling of gold." Additional references are given in vol iv., pp. I596, 1597 .

We naturally think of "Open, sesame!" in this connection, but of. Mr. Hartland's remarks, K'eport of the Folklore Congress of I89I, Pp. 28-30.-ED.] 